\title{
Evaluation of Therapeutic Thoracic Medial Branch Block Effectiveness in Chronic Thoracic Pain: A Prospective Outcome Study With Minimum 1-Year Follow UP
}

Laxmaiah Manchikanti, MD, Kavita N. Manchikanti, Rajeev Manchukonda, BDS, Vidyasagar Pampati, MSc, and Kim A. Cash, RT

Background: The prevalence of persistent upper back and mid back pain due to involvement of thoracic facet joints has been described in controlled studies as varying from $43 \%$ to $48 \%$ based on IASP criteria. Therapeutic intraventions utilized in managing chronic neck pain and low back pain of facet joint origin include intraarticular injections, medial branch nerve blocks, and neurolysis of medial branch nerves by means of radiofrequency. These interventions have not been evaluated in managing chronic thoracic pain of facet joint origin.

Objective: To determine the clinical effectiveness of therapeutic thoracic medial branch blocks in managing chronic upper back and mid back pain of facet joint origin. study.

Design: A prospective outcome

Setting: Interventional pain management setting in the United States.

Chronic persistent thoracic spinal pain is as disabling as neck and low back pain, even though it may be less common than low back or neck pain. Linton et al (1) estimated the prevalence of all spinal pain in the general population as $66 \%$, with $15 \%$ reporting thoracic pain, $44 \%$ reporting neck pain, and 56\% reporting low back pain. Edmondson and

From Pain Management Center of Paducah, Paducah, Kentucky.

Address Correspondence: Laxmaiah Manchikanti,MD, 2831 Lone Oak Road, Paducah, KY 42003

Funding: Facilities and funding were provided by Ambulatory Surgery Center and Pain Management Center of Paducah, Paducah, KY 42003

Email:drm@apex.net

Conflict of Interest: None

Disclaimer: There was no external funding in preparation of this manuscript.

Manuscript received on 2/17/2006

Revision received on $3 / 10 / 2006$

Accepted for publication on 3/15/2006
Methods: Fifty-five consecutive patients meeting the diagnostic criteria of thoracic facet joint pain by means of comparative, controlled diagnostic blocks were included in this evaluation. All medial branch blocks were performed in a sterile operating room under fluoroscopic visualization with mild sedation with midazolam and/or fentanyl. Statistical methods incorporated intent-to-treat analysis.

Outcome Measures: Numeric pain scores, significant pain relief $(\geq 50 \%)$, Oswestry Disability Index, work status and Pain Patient Profile ( $\left.\mathrm{P}-3^{\circledR}\right)$. Significant pain relief was defined as an average $50 \%$ or greater reduction of numeric pain rating scores.

Results: The results showed significant differences in numeric pain scores and significant pain relief $(50 \%$ or greater) in $71 \%$ of the patients at three months and six months, $76 \%$ at 12 months, $71 \%$ at

Singer (2) showed that even though the mechanical thoracic spinal pain is less common it can be as disabling as lumbar or cervical pain. Occhipiniti et al (3) reported a prevalence of thoracic pain of $5 \%$, in contrast to the prevalence of cervical and lumbar pain of $24 \%$ and $33 \%$ respectively. Anderson et al (4) described prevalence of thoracic pain in $10 \%$ to $28 \%$. Upon summarizing selective surveys Singer and Edmondson (5) found that the reported incidence of the occurrence of musculoskeletal complaints contributed to the thoracic region was $2 \%$ to $26 \%$, and its prevalence was $5 \%$ to $34 \%$. In the interventional pain management environment, the proportion of patients with thoracic disorders has been reported to be relatively small, ranging from $3 \%$ to $22 \%(6,7)$.
24 months, and $69 \%$ at 36 months, compared to baseline measurements. Functional improvement was demonstrated at one year, two years, and three years from baseline. There was significant improvement with increase in employment among the patients eligible for employment (employed and unemployed) from baseline to one year, two years, and three years $(61 \%$ vs $96 \%$ to $100 \%$ ) and improved psychological functioning.

Conclusion: Therapeutic thoracic medial branch blocks were an effective modality of treatment in managing chronic thoracic pain secondary to facet joint involvement confirmed by controlled, comparative local anesthetic blocks.

Key Words: Chronic thoracic pain, thoracic facet joint pain, medial branch blocks, comparative controlled local anesthetic blocks, therapeutic facet joint nerve blocks

Facet or zygapophysial joints have been implicated as the source of chronic pain in $43 \%$ to $48 \%$ of patients with chronic thoracic pain $(8,9)$. These figures were based on responses to controlled diagnostic blocks of these joints in accordance with the criteria established by the International Association for the Study of Pain (10). Even then, the role of thoracic facet joints in chronic upper back or mid back pain has received very little attention with only few publications discussing these joints as the source of pain production $(8,9,11-17)$.

As with the epidemiology and the clinical significance of thoracic facet joint pain, significant controversy surrounds various treatments utilized in the management of chronic thoracic pain arising from thoracic facet joints. 
However, this controversy is based on the publications in the cervical and lumbar region, rather than thoracic region. In managing chronic facet joint pain, therapeutic benefit is expected with three types of interventions. These include intraarticular injections, medial branch nerve blocks, and neurolysis of medial branch nerves by means of radiofrequency. The long-term therapeutic benefit of intraarticular injections of facet joints has been poor $(18,19)$. The evidence for long-term benefits of medial branch nerve blocks is moderate in managing chronic neck pain and low back pain (18-21); and radiofrequency neurotomy is supported with moderate evidence for long-term relief $(18,19$, $22,23)$ with some contradictory reports $(24,25)$. However, the role of any therapeutic thoracic facet joint interventions has not been evaluated.

In this prospective evaluation, we sought to evaluate the clinical effectiveness of therapeutic thoracic medial branch blocks after the diagnosis of thoracic facet joint pain was confirmed by comparative, controlled, local anesthetic blocks.

\section{Methods}

Fifty-five consecutive patients meeting the diagnostic criteria of thoracic facet joint pain by means of comparative, controlled diagnostic blocks and willingness to participate in this clinical evaluation as part of their continuing treatment were included. No financial or other incentive was provided. The study was performed in an interventional pain management setting in private practice.

All patients were given an explanation of the purpose of this study and an opportunity for discussion. They were also advised of the associated risks and given the choice as to whether or not they wanted to participate. Informed consent was then obtained. Appropriate precautions were taken to protect the privacy and anonymity of all of the patients participating in this study.

Prior to enrollment in the therapeutic phase, patients were evaluated for thoracic facet joint pain, based on historical, clinical, and radiological evaluation. Only patients with non-spe- cific thoracic pain with a duration of at least six months were included. Patients with disc-related pain with radicular symptoms were excluded based on radiologic testing, as was a lack of radicular symptoms or pain involving predominantly the chest wall. All patients included for the diagnosis of thoracic facet joint pain had failed conservative management, which included physical therapy, chiropractic manipulation, exercises, drug therapy, bedrest, etc.

Inclusion criteria included diagnosis of facet joint pain by means of comparative local anesthetic blocks, patients over 18 years of age, patients with a history of chronic, function-limiting thoracic pain of at least six months duration; patients who were able to provide voluntary, written informed consent to participate in this evaluation; patients who were able to understand this evaluation; patients willing to return for follow-ups, and patients without history of recent surgical procedures within the last three months.

Exclusion criteria included negative or false-positive responses to controlled comparative local anesthetic blocks, heavy narcotic usage, uncontrolled major depression or uncontrolled psychiatric disorders, uncontrolled or acute medical illness, chronic severe conditions that could interfere with interpretation of the outcome assessment, women who were pregnant or lactating, patients unable to be positioned prone, and patients with a history of adverse reaction to local anesthetic or anti-inflammatory drugs.

All the medial branch blocks were performed utilizing a posterior approach with the patient in the prone position with a pillow under the chest. The target points were identified as described by Bogduk (26). In general, the superolateral corners of the thoracic transverse processes were considered as target points. Bogduk (26) described the nerves to a particular joint to be the ones that cross the transverse process above the joint and the transverse process below the joint. T1-T4, T9 and T10 blocks were performed by advancing the needle until the contact was made with the back of the target transverse process. Subsequently, the needle was advanced so as to rest on the back of the superolateral corner of the transverse process. For medial branch blocks from $\mathrm{T} 5$ to $\mathrm{T} 8$, the needle made contact with the rib lying at the same depth as the back of the transverse process. For medial branch blocks at T11 and T12, the target point was at the junction of the superior articular process and the transverse process, which the target nerve crosses. Therapeutic facet joint nerve blocks were performed with bupivacaine with or without Sarapin and 1 mg Depo-Methyl Prednisolone per mL solution with injection of 1 to $1.5 \mathrm{~mL}$ solution per nerve.

Outcome measures included assessment of pain relief by numeric pain rating scale (NRS), significant pain relief ( $\geq 50 \%)$, functional assessment by Oswestry Disability Questionnaire, and psychological status by Pain Patient Profile $\left(\mathrm{P}-3^{\circledR}\right)$.

Therapeutic thoracic facet joint blocks were performed in accordance with Evidence-based Practice Guidelines for Interventional Techniques in the Management of Chronic Spinal Pain $(18,27)$ and Local Medical Review Polices (LMRPs) or Local Coverage Decisions (LCDs) of AdminaStar Federal of Kentucky and Indiana (28-31). The guidelines $(18,27)$ and Local Medical Review Policies or Local Coverage Decisions (28-31) indicate that, in the therapeutic phase (after the diagnosis is established), the frequency of facet joint nerve blocks should be two months or longer between each injection, provided that at least greater than $50 \%$ relief is obtained for six weeks. In the therapeutic phase, facet joint nerve blocks should be repeated only as necessary judging by the medical necessity criteria, and should be limited to a maximum of six times for local anesthetic and steroid blocks over a period of one year. In 2005, therapeutic facet joint block frequency was limited to four per year per region (29).

Based on these guidelines, after patients were enrolled in the study, each patient was evaluated and offered treatment; however, not exceeding six times per year in the therapeutic phase. Therapeutic facet joint nerve blocks were repeated based on the response to pri- 
or interventions with improvement in physical and functional status, and only upon increased levels of pain greater than $50 \%$ level or deterioration of relief to below $50 \%$.

Data collection included demographic data, assessment of pain with numeric pain rating scale at baseline, three months, six months, one year, two years, and three years. Functional assessment by Oswestry Disability Questionnaire, psychological evaluation with Pain Patient Profile (P-3) and work status were determined in each patient at baseline, three months, six months, one year, two years and three years. The same co-interventions as needed with narcotic and non-narcotic analgesics, adjuvant analgesics, and previously directed exercise program prior to enrollment were continued in all patients. No specific physical therapy, occupational therapy, bracing, or other specific interventions were included.

Employment and work status (employed, unemployed due to pain, housewife, disabled, and retired) were determined. Only employed and unemployed patients were considered to be eligible for employment, whereas disabled patients and retired patients were considered not employable.

\section{Statistical Methods}

Data were recorded on a database using Microsoft ${ }^{\circledR}$ Access $^{\circledR}$. The SPSS version 9.0 statistical package was used to generate the descriptive tables. Differences in proportions were tested using a chi-squared test. Fischer's Exact Test was used whenever the expected value was less than 5. A paired $t$-test was used to compare the pre- and post-treatment results of average pain score and psychological outcome measurements at baseline versus three months, six months, one year, two years and three years of time points. Bonferroni correction was done for multiple comparisons for the $t$ test. All results were considered statistically significant if the $P$ value was less than 0.05. An intent-to-treat analysis was performed in all patients. Last follow-up data or initial data were utilized in the patients who dropped out of the study due to poor response or with lack of follow-up data.

\section{RESULTS}

\section{Patient Flow}

Over a period of four years (January 2001 to December 2004), a total

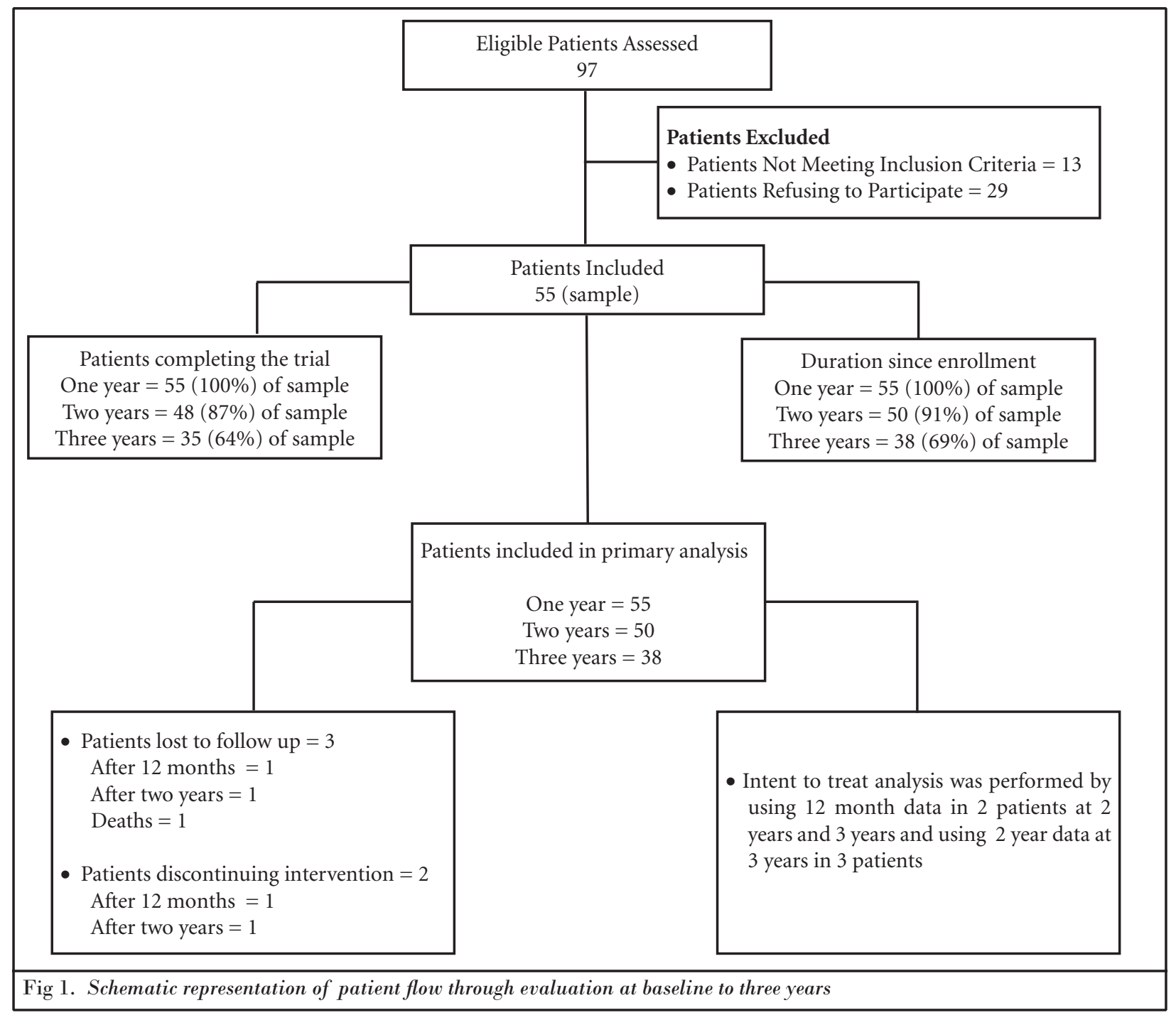


Table 1. Therapeutic procedural characteristics over a period of one year ( $n=55$ )

\begin{tabular}{|l|c|c|c|}
\hline $\begin{array}{l}\text { Number of procedures } \\
\text { in one year }\end{array}$ & $\begin{array}{c}\text { Number of } \\
\text { Patients }\end{array}$ & $\begin{array}{c}\text { Average relief Per } \\
\text { Procedure } \\
\text { (in weeks) }\end{array}$ & $\begin{array}{c}\text { Average Total Relief } \\
\text { (in weeks) } \\
\text { (Mean } \pm \text { SD) }\end{array}$ \\
\hline One & 5 & 52 & 52 \\
\hline Two & 5 & $\begin{array}{c}24.5 \pm 2.9 \\
(19-26)\end{array}$ & $\begin{array}{c}49.4 \pm 5.8 \\
(39-52)\end{array}$ \\
\hline Three & 5 & $\begin{array}{c}11.8 \pm 0.8 \\
(11-13)\end{array}$ & $\begin{array}{c}35.4 \pm 2.5 \\
(32-39)\end{array}$ \\
\hline Four & 32 & $\begin{array}{c}12.5 \pm 1.1 \\
(7-13)\end{array}$ & $\begin{array}{c}50 \pm 4.54 \\
(31-52)\end{array}$ \\
\hline Five & 8 & $\begin{array}{c}9.6 \pm 1.7 \\
(5-10)\end{array}$ & $\begin{array}{c}47.9 \pm 8.6 \\
(27-52)\end{array}$ \\
\hline Total & 55 & $16.7 \pm 11.2$ & $48.6 \pm 6.6$ \\
(for first year) & $(5-52)$ & $(27-52)$ \\
\hline
\end{tabular}

Table 2. Therapeutic procedural characteristics over a period of two years $(n=48)$

\begin{tabular}{|c|c|c|c|}
\hline $\begin{array}{l}\text { Number of procedures } \\
\text { in two years }\end{array}$ & $\begin{array}{l}\text { Number of } \\
\text { Patients }\end{array}$ & $\begin{array}{c}\text { Average relief Per } \\
\text { Procedure (in weeks) } \\
\text { (Mean } \pm \text { SD) }\end{array}$ & $\begin{array}{l}\text { Average Total Relief } \\
\text { (in weeks) } \\
(\text { Mean } \pm \text { SD) }\end{array}$ \\
\hline One & 5 & $\begin{array}{c}98.8 \pm 11.7 \\
(78-104)\end{array}$ & $\begin{array}{l}98.8 \pm 11.7 \\
(78-104\end{array}$ \\
\hline Two & 3 & 52 & 104 \\
\hline Three & 1 & 17 & 52 \\
\hline Four & 3 & $\begin{array}{c}19.5 \pm 7.5 \\
(11-26)\end{array}$ & $\begin{array}{l}78 \pm 30.1 \\
(45-104)\end{array}$ \\
\hline Five & 5 & $\begin{array}{c}17.5 \pm 4.5 \\
(12-21) \\
\end{array}$ & $\begin{array}{c}87.6 \pm 22.5 \\
(61-104) \\
\end{array}$ \\
\hline Six & 4 & $\begin{array}{c}11.5 \pm 1.5 \\
(9-13)\end{array}$ & $\begin{array}{r}68.8 \pm 9.3 \\
(57-78) \\
\end{array}$ \\
\hline Seven & 5 & $\begin{array}{l}14 \pm 0.9 \\
(12-15)\end{array}$ & $\begin{array}{c}98 \pm 6.7 \\
(87-104)\end{array}$ \\
\hline Eight & 16 & $\begin{array}{c}12.6 \pm 0.7 \\
(10-13)\end{array}$ & $\begin{array}{l}101 \pm 5.2 \\
(85-104)\end{array}$ \\
\hline Nine & 6 & $\begin{array}{c}11.4 \pm 0.2 \\
(11-22)\end{array}$ & $\begin{array}{l}102 \pm 2.1 \\
(94-104)\end{array}$ \\
\hline $\begin{array}{l}\text { Total } \\
\text { (for first } 2 \text { years) }\end{array}$ & 48 & $\begin{array}{l}25 \pm 27.5 \\
(9-104)\end{array}$ & $\begin{array}{l}94 \pm 16.1 \\
(45-104)\end{array}$ \\
\hline
\end{tabular}

of 201 patients with chronic thoracic pain, or suspected of having pain of facet joint origin, were evaluated utilizing controlled, comparative local anesthetic blocks. Of these patients, 97, after testing positive with both lidocaine and bupivacaine, were considered positive for thoracic facet joint pain. They were all assessed and offered the opportunity to participate in the study. Of the 97 assessed patients, 55 agreed to participate in the evaluation. Fig. 1 illustrates the participant flow diagram. All the patients were in the study for at least one year. In contrast, 50 patients were in the study for two years, whereas 38 patients were in the study for three years. A total of three patients were lost to follow-up, whereas two patients discontinued intervention. Intent-to-treat analysis was utilized in five patients. Patients available for follow-up were $55(100 \%)$ at end of one year, 48 of 50 $(96 \%)$ at end of two years, and 35 of 38 (92\%) at the end of three years.

\section{Demographic Characteristics}

Fifty-eight percent of the patients were female, with (mean \pm SD) age of $46 \pm 14.5$ years, height (mean \pm SD) of $67 \pm 3.8$ inches, and weight (mean \pm $\mathrm{SD}$ ) of $171 \pm 42.2 \mathrm{lbs}$. Average duration of pain (mean \pm SD) was $107+97.4$ months with $35 \%$ of patients reporting onset following an incident, and 31\% with a history of previous surgery.

\section{Procedural Characteristics}

The number of joints involved was as follows: two joints were involved in $20 \%$ of the patients, three joints were involved in $64 \%$ of the patients, and four joints were involved in $16 \%$ of the patients. Bilateral involvement was seen in $60 \%$ of the patients.

The average number of treatments (mean \pm SD) per patient over a period of one year were $4 \pm 1.1$ with a range of 1 to 5 ; they were $6 \pm 2.6$ with a range of 1 to 9 over a period of two years, and 9 \pm 4.1 with a range of 1 to 13 over a period of three years. When calculating the data for all three years, the average relief for therapeutic blocks was $16.3 \pm$ 27.4 weeks (mean $\pm \mathrm{SD}$ ).

Tables 1 to 3 illustrate procedural characteristics with frequency and number of procedures. These procedures do not include the diagnostic blocks performed with lidocaine and bupivacaine prior to enrolling in the study. The relief obtained and the period during which the diagnostic blocks were performed is not included in the one-year period. A total of 47 of 55 or $85 \%$ of the patients received one to four procedures over a one-year period, 42 of 48 or $88 \%$ of the patients received one to eight procedures over a period of two years, and 33 of 35 or $94 \%$ of the patients received one to twelve procedures over a period of three years. Four patients reported three years of relief with one procedure.

\section{Pain Relief}

Numeric pain scale report at baseline and at three months, six months, 12 months, two years, and three years is illustrated in Table 4. There were significant differences with baseline values at three, six, 12 months, two years, and three years. Fig. 2 shows the proportion of patients with significant relief, which was defined as relief of $50 \%$ 
Table 3. Therapeutic procedural characteristics over a period of three years ( $n=35$ )

\begin{tabular}{|c|c|c|c|}
\hline $\begin{array}{l}\text { Number of } \\
\text { procedures } \\
\text { in three years }\end{array}$ & $\begin{array}{l}\text { Number of } \\
\text { Patients }\end{array}$ & $\begin{array}{c}\text { Average relief Per } \\
\text { Procedure (in weeks) } \\
(\text { Mean } \pm \text { SD) }\end{array}$ & $\begin{array}{l}\text { Average Total Relief } \\
\text { (in weeks) } \\
\text { (Mean } \pm \text { SD) }\end{array}$ \\
\hline One & 4 & $\begin{array}{c}136.5 \pm 39.0 \\
(78-156)\end{array}$ & $\begin{array}{c}136.5 \pm 39.0 \\
(78-156)\end{array}$ \\
\hline Two & 2 & 78 & 156 \\
\hline Four & 1 & 39 & 156 \\
\hline Five & 2 & 31.2 & 156 \\
\hline Six & 1 & 21 & 124 \\
\hline seven & 3 & $\begin{array}{c}14.2 \pm 4.6 \\
(10-19)\end{array}$ & $\begin{array}{c}99.3 \pm 32.3 \\
(75-136)\end{array}$ \\
\hline Nine & 3 & $\begin{array}{l}16.3 \pm 1.7 \\
(14-17)\end{array}$ & $\begin{array}{l}147.3 \pm 15.0 \\
(130-156)\end{array}$ \\
\hline Ten & 2 & $\begin{array}{l}12.3 \pm 1.0 \\
(11-13)\end{array}$ & $\begin{array}{c}123 \pm 9.9 \\
(116-130)\end{array}$ \\
\hline Eleven & 2 & $\begin{array}{c}12.7 \pm 1.6 \\
(10-14)\end{array}$ & $\begin{array}{l}139.5 \pm 17.7 \\
(127-152)\end{array}$ \\
\hline Twelve & 13 & $\begin{array}{l}12.4 \pm 0.9 \\
(10-13)\end{array}$ & $\begin{array}{l}148.6 \pm 10.4 \\
(123-156)\end{array}$ \\
\hline Thirteen & 2 & $\begin{array}{c}11.7 \pm 0.2 \\
(11-12)\end{array}$ & $\begin{array}{r}151.5 \pm 2.12 \\
(150-153) \\
\end{array}$ \\
\hline $\begin{array}{c}\text { Total } \\
\text { (for all } 3 \text { years) }\end{array}$ & 35 & $\begin{array}{c}32.8 \pm 42.6 \\
(10-156)\end{array}$ & $\begin{array}{c}141.4 \pm 22.5 \\
(75-156)\end{array}$ \\
\hline
\end{tabular}

Table 4. Illustration of numeric pain scale scores

\begin{tabular}{|l|c|c|}
\hline & Number of patients & Scores $($ Mean \pm SD) \\
\hline Baseline & 55 & $7.7 \pm 0.91$ \\
\hline 3 months & 55 & $3.3^{\star} \pm 0.68$ \\
\hline 6 months & 55 & $3.3^{\star} \pm 0.65$ \\
\hline 1 year & 55 & $3.2^{\star} \pm 0.66$ \\
\hline 2 years & 50 & $3.4^{\star} \pm 1.12$ \\
\hline 3 years & 38 & $3.2^{\star} \pm 0.75$ \\
\hline
\end{tabular}

${ }^{*}$ Indicates significant difference with baseline values $(\mathrm{p}<0.001)$

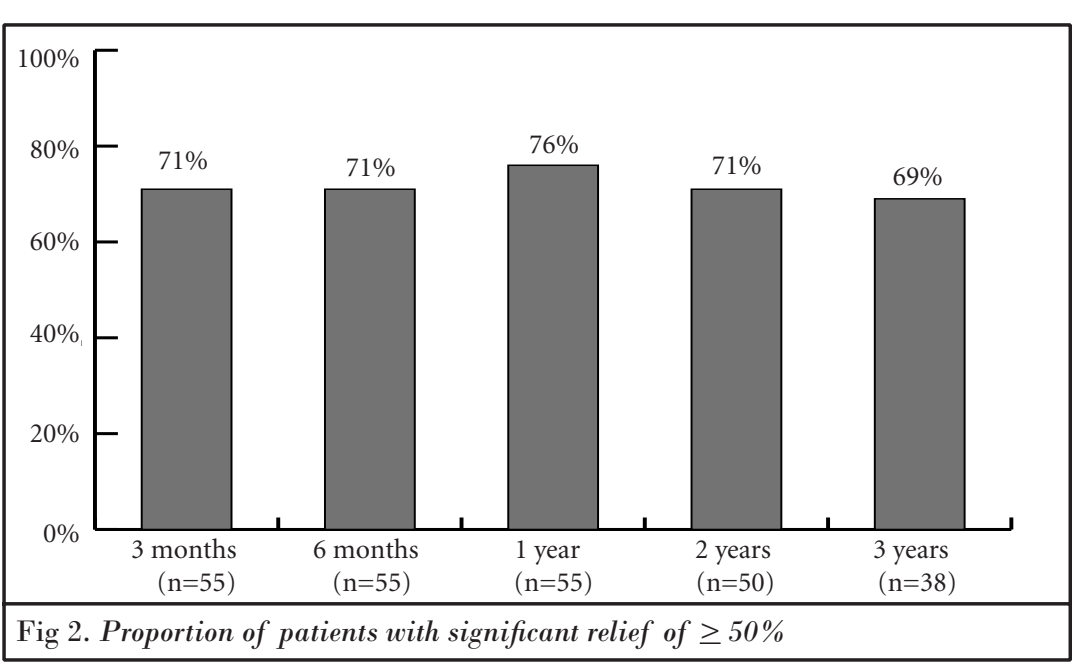

or greater at three, six, 12 months, two years, and three years.

\section{Outcome Measures}

Functional measures included the Oswestry Disability Index and psychological measures included evaluation using the Pain Patient Profile (P-3). Employment status was also evaluated at pre-treatment, at 12 months, two years, and three years

Fig. 3 illustrates functional measures as assessed by the Oswestry Disability Index. Fig. 4 and Table 5 illustrate findings of the psychological evaluation. Psychological diagnosis was made based on scores of the P-3 evaluation. Depression was diagnosed with scores of 55 or higher, whereas scores of 56 or higher for anxiety and somatization represented the diagnosis. Table 5 shows the changes in the psychological status from baseline to three years. Fig. 4 illustrates the proportion of patients with a diagnosis of depression, anxiety, and somatization at baseline and posttreatment. There was significant improvement noted in all aspects at all intervals of assessment.

\section{Employment Status}

Table 6 shows employment status. Among the patients eligible for employment (employed and unemployed due to pain) there was significant improvement with increase in employment with total employed of 14 of 23 employable with 22 employed of 22 employable with none unemployed at the end of one year, 19 of 20 employed at the end of two years, and 13 of 13 employed at the end of three years.

\section{Adverse Events}

There were no adverse events reported during this study.

\section{DISCUSSION}

This prospective evaluation showed significant pain relief in $71 \%$ of the patients at three months and six months, $76 \%$ at 12 months, $71 \%$ at two years and $69 \%$ at three years. Assessment of pain by numeric pain rating scale also showed significant improvement at three, six, 12, 24 and 36 months. This study demonstrat- 


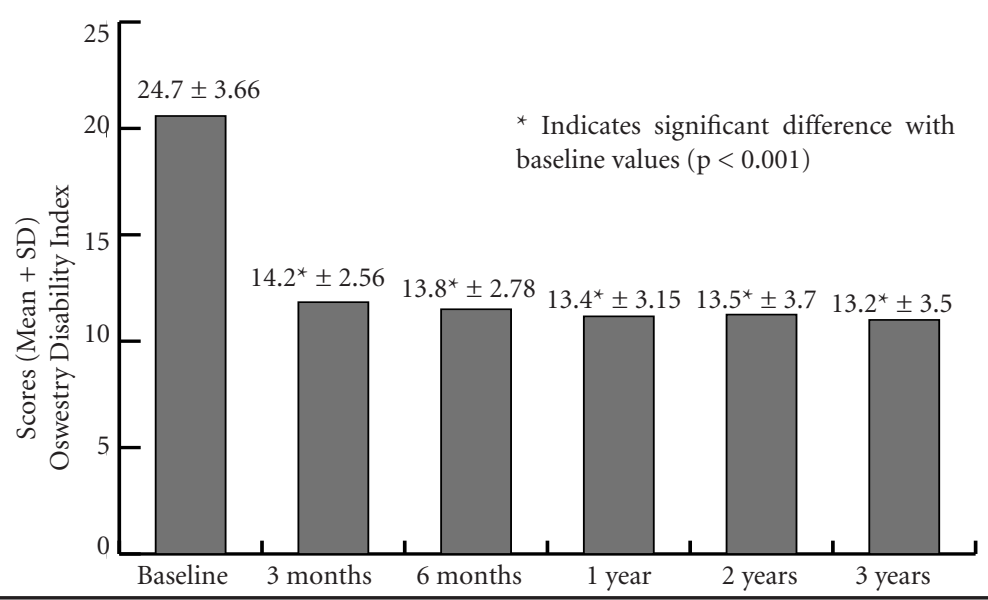

Fig 3. Functional measurement by Oswestry Disability Index

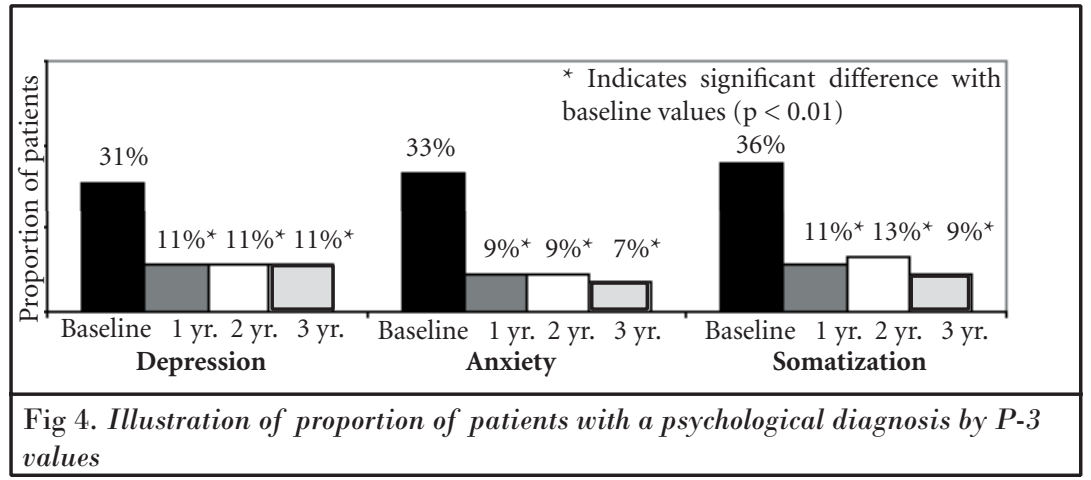

Table 5. Analysis of psychological outcome measurements by $P$-3 evaluation scores $($ Mean $\pm S D)$

\begin{tabular}{|l|c|c|c|}
\hline & Depression & Anxiety & Somatization \\
\hline Baseline & $46.9 \pm 11.26$ & $47.8 \pm 12.71$ & $48.8 \pm 13.58$ \\
\hline 3 months & $45.7 \pm 11.39$ & $46.2 \pm 12.12$ & $47.2 \pm 12.19$ \\
\hline 6 months & $41.4^{*} \pm 12.41$ & $41.1^{\star} \pm 13.13$ & $40.2^{*} \pm 13.93$ \\
\hline 1 year & $39.6^{*} \pm 11.75$ & $39.0^{*} \pm 12.15$ & $39.6^{*} \pm 12.45$ \\
\hline 2 years & $39.2^{\star} 11.88$ & $38.4^{*} \pm 12.46$ & $39.4^{*} \pm 12.49$ \\
\hline 3 years & $38.8^{\star} \pm 11.47$ & $37.4^{*} \pm 12.64$ & $38.1^{*} \pm 12.64$ \\
\hline
\end{tabular}

${ }^{*}$ Indicates significant difference with baseline values $(\mathrm{p}<0.001)$

Table 6. Illustration of employment status

\begin{tabular}{|c|c|c|c|c|}
\hline & $\begin{array}{c}\text { Baseline } \\
\mathrm{n}=55\end{array}$ & $\begin{array}{c}1 \text { year } \\
\mathrm{n}=55\end{array}$ & $\begin{array}{c}2 \text { years } \\
\mathrm{n}=50\end{array}$ & $\begin{array}{c}3 \text { years } \\
\mathrm{n}=38\end{array}$ \\
\hline Total employed & $\begin{array}{c}\mathbf{1 4} \\
\mathbf{6 1 \%}\end{array}$ & $\begin{array}{c}\mathbf{2 2} \\
(\mathbf{1 0 0} \%)^{*}\end{array}$ & $\begin{array}{c}\mathbf{1 9} \\
(\mathbf{9 5 \%})^{*}\end{array}$ & $\begin{array}{c}\mathbf{1 3} \\
(\mathbf{1 0 0} \%)^{*}\end{array}$ \\
\hline Employed full-time & 11 & 16 & 14 & 10 \\
\hline Employed part-time & 3 & 6 & 5 & 3 \\
\hline Unemployed due to pain & 7 & 0 & 1 & 0 \\
\hline Eligible for Employment & $\mathbf{2 3}$ & $\mathbf{2 2}$ & $\mathbf{2 0}$ & $\mathbf{1 3}$ \\
\hline Disabled & 21 & 22 & 20 & 17 \\
\hline Over 65 and Housewife & 11 & 11 & 10 & 8 \\
\hline Total Number of Patients & 55 & 55 & 50 & 38 \\
\hline
\end{tabular}

\# Percentage of employment was calculated only for eligible for employment

${ }^{*}$ Indicates significant difference with baseline values $(\mathrm{p}<0.001)$ ed that there was significant improvement in functional status, psychological status, and work status. The results are important in that the patients in the study represented a subset of patients in whom various non-interventional conservative mangement modalities had failed. Consequently, these observations demonstrate the potential usefulness of thoracic therapeutic facet joint nerve blocks in the management of chronic upper back and mid back pain, where the diagnosis has been confirmed by controlled, comparative local anesthetic blocks, utilizing IASP criteria.

The current study is the first to have treated patients with chronic thoracic pain confirmed as facet joint pain with controlled diagnostic blocks utilizing therapeutic medial branch blocks. Further, the study also utilized objective outcome measures. The results are similar to previously published studies illustrating the effectiveness of therapeutic medial branch blocks in the cervical and lumbar spine $(20,21)$.

In general, there is a paucity of literature on the role of therapeutic medial branch or facet joint nerve blocks in the literature. While the role of diagnostic facet joint nerve blocks is well delineated $(26,32,33)$, the literature on therapeutic facet joint nerve blocks is limited $(20,21)$. The explanation of the effectiveness of therapeutic nerve blocks may be based on the neurolytic activity of the blockade or various unknown effects of neural blockade providing relief lasting much longer than the pharmacological duration of the drugs utilized. The explanation follows the philosophy that unexplained benefits are achieved from neural blockade with overall benefit of various types of injection techniques including pain relief outlasting by days, weeks, or months, the relatively short duration of pharmacological action of the local anesthetic and other agents used. Clear-cut explanations for these benefits, of course, are not currently available specifically for facet joint nerve blocks. It is believed that facet joint nerve blocks, similar to other nerve blocks, alter or interrupt nociceptive input mechanisms of afferent limb, self sustaining activities of the neuron pools and neuraxis, and the pattern of 
central neuronal activities (34). Further, additional explanations may be provided with a possibility that pain relief may result from blockade of pain fibers from muscles innervated by the medial branch nerves, i.e., deep paramedian muscles. The explanations in part are based on the pharmacological and physical actions of the various drugs employed including local anesthetics, corticosteroids, and other agents. Further, it is also believed that local anesthetics interrupt the pain spasm cycle and reverberating nociceptive transmission; whereas corticosteroids reduce inflammation either by inhibiting the synthesis or the release of a number of proinflammatory substances (35-41). Local anesthetics also have been shown to produce prolonged dampening of C-fiber activity (42-44). Consequently, corticosteroids may inhibit sensitized nerves by suppressing spontaneous neuron depolarization. While the scientific basis of some of these concepts, at least in part, has proven the management of discogenic pain particularly with epidural injections or betamethasone and intravenous methylprednisolone $(39,45-48)$, there is no such explanation for therapeutic facet joint nerve blocks.

While the study is far short of providing definitive evidence, it provides the basis for a randomized, double-blind trial, with or without placebo control. Even then, the value of observational studies become increasingly important. Concato et al (49) and others (50-55) have reinforced the value of prospective trials. However, supporting a prospective trial does not undermine the importance of a randomized double-blind, controlled trial, with or without placebo control. Indeed, flaws can exist in a study design or analysis, both in non-randomized and randomized trials (49-55).

This study does possess many advantages in that it was performed in a clinical setting with reasonable followup and assessment of multiple outcome parameters. Multiple procedures were provided, as most interventional procedures, including epidural steroids and facet joint interventions, provide shortterm relief with the first treatment.
Long-term improvement is only feasible with repeat interventions. The concept of multiple procedures has been a common phenomenon with interventional techniques (18-21, 27-31, 56-60).

The blocks have been performed as described by Bogduk identifying the target points (26). Chua and Bogduk (61) have described the anatomy of the medial branches. They showed that the medial branches of the thoracic dorsal rami do not assume the same course at different levels. The nerves at mid-thoracic levels do not run on bone, but instead are suspended in the intertransverse space. Chua and Bogduk (61) also reported that the thoracic medial branches are not that close to the facet joint, as they swing laterally to circumvent the multifidus. Consequently, the target points for blocks of these nerves are relatively intangible and require judgments about how far to withdraw the needle from the bone rather than resting the needle on a radiographically visible bony landmark. However, earlier information with much of the systematic innervation of the human spine has been extrapolated from the comprehensive description of that in the monkey by Stilwell from 1956 (62). Free nerve endings have been demonstrated in the capsules of the facet joints. Analogous to the innervation of the cervical and lumbar facet joints, the thoracic facet joints receive a bi-segmental innervation from the medial branches of the dorsal ramus of the upper segment and one or more cephalad level(s) (61, 63). Thus, facet joints T6/T7, for example, are supplied by $\mathrm{T} 5$ and $\mathrm{T} 6 \mathrm{spi-}$ nal nerves.

In summary, this prospective evaluation showed that therapeutic thoracic facet joint nerve blocks reduced pain and improved functional status with return to work in a significant number of patients who were deemed eligible.

\section{ConcLusion}

Therapeutic thoracic medial branch blocks were an effective modality of treatment in managing chronic upper and mid-back pain secondary to facet joint involvement confirmed by controlled, comparative local anesthetic blocks. Therapeutic thoracic medial branch blocks were effective in providing significant pain relief, improvement in functional status, improvement in overall functional status, improvement in overall psychological status, and return to work, without adverse events.

\section{ACKNOWLEDGMENTS}

The authors wish to thank Tonie D. Hatton and Diane E. Neihoff, transcriptionists, and Kim S. Damron, RN, Carla D. McManus, RN, Sheila D. Jackson, RN, Doris E. Brandon, CST, and Sue R. Wilson, ORT, for their assistance and preparation of this manuscript.

The authors also wish to thank the Editorial Board of Pain Physician for their constructive criticism, review, and advice.

Author Affiliation:

Laxmaiah Manchikanti, MD

Medical Director

Pain Management Center of Paducah

2831 Lone Oak Road

Paducah, Kentucky 42003

Associate Clinical Professor of

Anesthesiology and Perioperative

Medicine

University of Louisville, Kentucky

40292

E-mail:drm@apex.net.

\section{Kavita N. Manchikanti}

Research Assistant

Pain Management Center of Paducah

2831 Lone Oak Road

Paducah, Kentucky 42003

\section{Rajeev Manchukonda, BDS}

Research Assistant

Pain Management Center of Paducah

2831 Lone Oak Road

Paducah, Kentucky 42003

E-mail: rajeev@thepainmd.com

\section{Vidyasagar Pampati, MSc}

Statistician

Pain Management Center of Paducah 2831 Lone Oak Road

Paducah, Kentucky 42003

E-mail: sagar@thepainmd.com

\section{Kim Cash, RT}

Ambulatory Surgery Center

2831 Lone Oak Road

Paducah, Kentucky 42003

E-mail:kim@thepainmd.com 


\section{REFERENCES}

1. Linton SJ, Hellsing AL, Hallden K. A population based study of spinal pain among 35-45-year old individuals. Spine 1998; 23:1457-1463.

2. Edmondson SJ, Singer KP. The thoracic spine: Anatomical and biomechanical considerations for manual therapy. Man Ther 1997; 2:132-143.

3. Occhipiniti E, Colombini D, Grieco A. Study of distribution and characteristics of spinal disorders using a validated questionnaire in a group of male subjects not exposed to occupational spinal risk factors. Spine 1993; 18:11501159.

4. Anderson R, Meeker WC, Wieick BE, Mootz RD, Kirk DH, Adams A. A metaanalysis of clinical trials of spinal manipulation. JMPT 1992; 15:181-194.

5. Singer KP, Edmondston SJ. Introduction: The enigma of the thoracic spine. In Giles GF, Singer KP (eds). Clinical Anatomy and Management of Thoracic Spine Pain. Butternorth Heineman, Boston, 2000; pp 3-15.

6. Stolker RJ, Vervest AC, Ramos LM, Groen GJ. Electrode positioning in thoracic percutaneous partial rhizotomy: An anatomical study. Pain 1994; 57: 241-251.

7. Manchikanti L, Pampati VS. Research designs in interventional pain management: Is randomization superior, desirable or essential? Pain Physician 2002;5:275-284.

8. Manchikanti L, Singh V, Pampati VS, Beyer C, Damron K. Evaluation of the prevalence of facet joint pain in chronic thoracic pain. Pain Physician 2002; 5: 354-359.

9. Manchikanti L, Boswell MV, Singh V, Pampati VS, Damron KS, Beyer CD. Prevalence of facet joint pain in chronic spinal pain of cervical, thoracic, and lumbar regions. BMC Musculoskelet Disord 2004; 5:15.

10. Merskey H, Bogduk N. Classification of chronic pain: Descriptions of chronic pain syndromes and definitions of pain terms. Second Edition. IASP Press, Seattle, 1994.

11. Dreyfuss P, Tibiletti C, Dreyer SJ. Thoracic zygapophyseal joint pain patterns: A study in normal volunteers. Spine 1994; 19:807-811.

12. Dreyfuss P, Tibiletti C, Dreyer S, Sobel J. Thoracic zygapophyseal pain: A review and description of an intraarticular block technique. Pain Digest 1994; 4: 46-54.

13. Skubic JW, Kostuik JP. Thoracic pain syndromes and thoracic disc herniation. In Frymoyer JW (ed). The Adult Spine. Ra- ven Press, New York, 1991:1443-1461.

14. Wilson PR. Thoracic facet joint syndrome - A clinical entity? Pain Suppl 1987; 4:S87.

15. Stolker RJ, Vervest AC, Groen GJ. Percutaneous facet denervation in chronic thoracic spinal pain. Acta Neurochir 1993; 122:82-90.

16. Stolker RJ, Vervest AC, Groen GJ. Parameters in electrode positioning in thoracic percutaneous facet denervation: An anatomical study. Acta Neurochir 1994; 128:32-39.

17. Stolker RJ, Vervest AC, Groen GJ. The treatment of chronic thoracic segmental pain by radiofrequency percutaneous partial rhizotomy. I Neurosurg 1994; 80:986-992.

18. Boswell MV, Shah RV, Everett CR, Sehgal N, Mckenzie-Brown AM, Abdi S, Bowman RC, Deer TR, Datta S, Colson JD, Spillane WF, Smith HS, Lucas-Levin LF, Burton AW, Chopra P, Staats PS, Wasserman RA, Manchikanti L. Interventional techniques in the management of chronic spinal pain: Evidencebased practice guidelines. Pain Physician 2005; 8:1-47.

19. Boswell MV, Colson JD, Spillane WF. Therapeutic facet joint interventions in chronic spinal pain: A systematic review of effectiveness and complications. Pain Physician 2005; 8:101-114

20. Manchikanti L, Manchikanti KN, Damron $\mathrm{K}$, Pampati VS. Effectiveness of cervical medial branch blocks in chronic neck pain: a prospective outcome study. Pain Physician 2004; 7:195-201.

21. Manchikanti L, Pampati VS, Bakhit CE, Rivera JJ, Beyer CD, Damron KS, Barnhill RC. Effectiveness of lumbar facet joint nerve blocks in chronic low back pain: $\mathrm{A}$ randomized clinical trial. Pain Physician 2001; 4: 101-117.

22. Lord SM, Barnsley L, Bogduk N. Percutaneous radiofrequency neurotomy in the treatment of cervical zygapophyseal joint pain: a caution. Neurosurgery 1995; 35:732-739.

23. Manchikanti L, Singh V, Vilims BD, Hansen HC, Schultz DM, Kloth DS. Medial branch neurotomy in management of chronic spinal pain: Systematic review of the evidence. Pain Physician 2002; 5:405-418.

24. Geurts JW, van Wijk RM, Stolker RJ, Groen GJ. Efficacy of radiofrequency procedures for the treatment of spinal pain: A systematic review of randomized clinical trials. Reg Anesth Pain Med 2001; 26:394-400.

25. Niemistö L, Kalso E, Malmivaara A, Seitsalo S, Hurri H; Cochrane Collaboration Back Review Group. Radiofrequency denervation for neck and back pain: A sys- tematic review within the framework of the Cochrane Collaboration Back Review Group. Spine 2003; 28:1877-1888.

26. Bogduk N. International Spinal Injection Society guidelines for the performance of spinal injection procedures. Part 1: Zygapophyseal joint blocks. Clin J Pain 1997; 13:285-302.

27. Manchikanti L, Staats PS, Singh V, Schultz DM, Vilims BD, Jasper JF, Kloth DS, Trescot AM, Hansen HC, Falasca TD, Racz GB, Deer T, Burton AW, Helm S, Lou L, Bakhit CE, Dunbar EE, Atluri SL, Calodney AK, Hassenbusch S, Feler CA. Evidence-based practice guidelines for interventional techniques in the management of chronic spinal pain. Pain Physician 2003; 6:3-80.

28. Adminastar Federal Paravertebral Facet loint Nerve Block (Diagnostic or Therapeutic) Policy. Policy Number AC-02034. Effective Date 12/15/2002.

29. Adminastar Federal Paravertebral Facet Joint Nerve Block (Diagnostic or Therapeutic) Policy. LCD Database ID Number L7848. Effective Date 09/20/2005.

30. Adminastar Federal Paravertebral Facet Nerve Denervation Policy. Policy Number AC-02-035. Effective Date 12/15/ 2002.

31. Adminastar Federal Paravertebral Facet Nerve Denervation Policy. LCD Database ID Number L8527. Effective Date 09/20/2005.

32. Boswell MV, Singh V, Staats PS, Hirsch IA. Accuracy of Precision Diagnostic Blocks in the Diagnosis of Chronic Spinal Pain of Facet or Zygapophysial Joint Origin: A Systematic Review. Pain Physician 2003;6:449-456.

33. Sehgal N, Shah RV, McKenzie-Brown A, Everett CR. Diagnostic utility of facet (zygapophysial) joint injections in chronic spinal pain: A systematic review of evidence. Pain Physician 2005; 8:211-224

34. Fox AJ, Melzack R. Transcutaneous electrical stimulation to acupuncture. Com parison of treatment of low back pain. Pain 1976; 2:141-148.

35. Devor M, Govrin-Lippmann R, Raber P. Corticosteroids suppress ectopic neural discharges originating in experimental neuromas. Pain 1985; 22:127-137.

36. Hua SY, Chen YZ. Membrane receptormediated electrophysiological effects of glucocorticoid on mammalian neurons. Endocrinology 1989; 124:687691.

37. Johansson A, Hao J, Sjolund B. Loca corticosteroid application blocks transmission in normal nociceptor C-fibers. Acta Anaesthesiol Scand 1990; 34:335338. 
38. Faber LE, Wakim NG, Duhring JL. Evolving concepts in the mechanism of steroid action: Current developments. $A m$ J Obstet Gynecol 1987; 156:1449-1458.

39. Olmarker K, Byrod G, Cornefjord M, Nordborg C, Rydevik B. Effects of methylprednisolone on nucleus pulposus-induced nerve root injury. Spine 1994; 19: 1803-1808.

40. Nicol GD, Klingberg DK, Vasko MR. Prostaglandin E2 enhances calcium conductance and stimulates release of substance $\mathrm{P}$ in avian sensory neurons. $J$ Neurosci 1992; 12:1917-1927.

41. Fowler RJ, Blackwell GJ. Anti-inflammatory steroid induced biosynthesis of a phospholipase A2 inhibitor which prevents prostaglandin generation. Nature 1979; 278:456-459.

42. Li YM, Wingrove DE, Too HP, Marnerakis M, Stimson ER, Strichartz GR, Maggio JE. Local anesthetics inhibit substance $P$ binding and evoked increases in intracellular $\mathrm{Ca}_{2+}$. Anesthesiology 1995; 82: 166-173.

43. Bonica JJ, Backup PH, Anderson CE. Peridural block, an analysis of 3,637 cases. A review. Anesthesiology 1957; 18:723-734.

44. Fink BR, Cairns AM. Differential use-dependent (frequency-dependent) effects in single mammalian axons: Data and clinical considerations. Anesthesiology 1987; 67:477-484.

45. Hayashi N, Weinstein JN, Meller ST, Lee HM, Spratt KF, Gebhart GF. The effect of epidural injection of betamethasone or bupivacaine in a rat model of lumbar radiculopathy. Spine 1998; 23:877885.

46. Lee HM, Weinstein JN, Meller ST, Hayashi N, Spratt KF, Gebhart GF. The role of steroids and their effects on phospholipase $A_{2}$. An animal model of radiculopathy. Spine 1998; 23:11911196.

47. Minamide A, Tamaki T, Hashizume $\mathrm{H}$, Yoshida M, Kawakami M, Hayashi N. Effects of steroids and lipopolysaccharide on spontaneous resorption of herniated intervertebral discs. An experience study in the rabbit. Spine $1998 ; 23: 870-$ 876.

48. Kingery WS, Castellote JM, Maze M. Methylprednisolone prevents the development of autotomy and neuropathic edema in rats, but has no effect on nociceptive thresholds. Pain 1999; 80: 555-566.

49. Concato J, Shah N, Horwitz RI. Randomized, controlled trials, observational studies, and the hierarchy of research designs. N Engl J Med 2000; 342:18871892.

50. Lenrow DA, Chou LH. Randomized controlled trials in interventional spine: perils and pitfalls. Pain Physician 2003; 6:83-88.

51. Pocock SJ, Elbourne DR. Randomized trails or observational tribulations? New Engl J Med 2000; 342;1907-1909.

52. Kunz R, Khan KS, Neumayer H. Observational studies and randomized trials. New Engl J Med 2000; 343:1194.

53. Sacks HS. Observational studies and randomized trials. New Engl J Med 2000; 343:1195.

54. Liu PY, Anderson G, Crowley JJ. Observational studies and randomized trials. New Engl J Med 2000; 343:1195.

55. Friedman HS. Observational studies and randomized trials. $N$ Engl J Med 2000; 343:1195-1996.

56. Epidural corticosteroid injections for sciatica due to herniated nucleus pulposus. N Engl / Med 1997; 336:16341640.

57. Carette S, Leclaire R, Marcoux S, Morin F, Blaise GA, St-Pierre A, Truchon R, Parent $F$, Levesque J, Bergeron V, Montminy $\mathrm{P}$, Blanchette C. A controlled trial of corticosteroid injections into facet joints for chronic low back pain. N Engl J Med 1991; 325:1002-1007.

58. Boswell MV, Hansen HC, Trescot AM, Hirsch JA. Epidural steroids in the management of chronic spinal pain and radiculopathy. Pain Physician 2003; 6: 319-334.

59. Abdi S, Datta S, Lucas LF. Role of epidural steroids in the management of chronic spinal pain: a systematic review of effectiveness and complications. Pain Physician 2005; 8:127-143.

6o. Riew KD, Yin Y, Gilula L, Bridwell KH, Lenke LG, Lauryssen C, Goette K. The effect of nerve root injections on the need for operative treatment of lumbar radicular pain. J Bone Joint Surg 2000; 82A: 1589-1593.

61. Chua WH, Bogduk N. The surgical anatomy of thoracic facet denervation. Acta eurochir 1995; 136:140-144.

62. Stilwell DL. The nerve supply of the vertebral column and its associated structures in the monkey. Anat Rec 1956; 125:139-169.

63. Stolker RJ, Vervest ACM, Groen GJ, De Ruiter JW, Hansen L.. On the innervation of the dorsal compartment of the thoracic spine. In Stolker RJ, Vervest AC (eds). Pain Management by Radiofrequency Procedures in the Cervical and Thoracic Spine: A Clinical and Anatomical Study. Thesis, Utrecht; 1994; pp 133144. 